\title{
Comparison of Specific Inhalation Challenge Test Results in Occupational and Non- Occupational Asthma Patients: Is Monitoring Peak Expiratory Flow Rate Sufficient for Diagnosis?
}

\author{
Cebrail Simsek ${ }^{1}$, Bilge Akgunduz ${ }^{1,2 *}$ and Gulden Sari ${ }^{1}$ \\ ${ }^{1}$ Ataturk Chest Diseases and Thoracic Surgery Hospital, Health Science University, Turkey \\ ${ }^{2}$ Occupational Diseases \& Chest Diseases Clinic, Eskişehir City Hospital, Turkey
}

Submission: October 28, 2021; Published: November 19, 2021

*Corresponding author: Bilge Akgunduz, Occupational Diseases \& Chest Diseases Clinic, Eskișehir City Hospital, 71 Evler, Çevre Yolu, 26080 Odunpazarl, Eskișehir, Turkey

Abstract

Objective: It is recommended to monitoring PEFR to diagnosing OA. Gold standard method is SIC test. The aim of this study is to evaluate comparison of SIC test results in patients with OA and non-OA and to discuss PEFR monitoring and underdiagnosed.

Materials and Methods: 24 patients (16 OA, 8 non-OA) who underwent SIC test were analyzed retrospectively.

Results: Although number of patients exposed to LMW (wood powders [n: 5]) was higher, IgE level was found significantly higher at OA $(697.39 \pm 839.36 \mathrm{kU} / \mathrm{ml})(\mathrm{p}: 0.027)$. Average PEFR monitoring days mean was $26.53 \pm 12.90 .13$ patients who diagnosed with OA with SIC was evaluated PEFR monitoring results were negative [\%92.86]. Minimum FEV1 value on exposure day was lower in OA (p:0.001).

Conclusion: We detected underdiagnosed cases rates were higher with diagnosing OA with PEFR monitoring alone. Our study also demonstrated that LMW agents cause immunological OA, independently from agent type and duration of exposure.

Keywords: Occupational asthma; Peak Expiratory Flow Rate; Specific Inhalation Challenge Test; Pneumoconiosis; Non-smokers

Abbreviations: OA: Occupational Asthma; RAST: Radioallergosorbent Test; LMW: Low Molecular Weight; HMW: High Molecular Weight; SPT: Skin Prick Test; SIC: Specific Inhalation Challenge; PEFR: Peak Expiratory Flow Rate

Main points

I. The specific etiological agent is difficult to detect in OA.

II. The gold standard method for diagnosing occupational asthma and identify exposure agent is specific bronchial provocation test.

III. PEFR monitoring cannot detect the agent responsible for OA.

\section{Introduction}

OA has become the second most common occupational lung disease after pneumoconiosis in the developing countries [1]. About $10-25 \%$ of adult-onset asthma cases are caused by occupational exposures [2]. More than 200 specific agents encountered at work can cause asthma [3]. It is recommended that occupational asthma should be suspected in every newly diagnosed adult asthma [4]. As opposed to the conventional diagnosis of pneumoconiosis, which is based only on the history of exposure and chest radiograph abnormalities, OA should be confirmed by objective means. The most important step to diagnosing $\mathrm{OA}$ is to take a detailed occupational exposure history. It follows by tests that will determine the relationship between the agent and the disease. It is difficult to detect the exposure agent that is cause asthma and/or establish direct causal relationship between the suspected occupational exposure agent and asthma.

The most expanded method to diagnosing OA is Peak Expiratory Flow Rate monitoring [5]. Specificity and sensitivity of PEF monitoring is lower than SIC test $[6,7]$. Changes in at work 
and away from work may show the presence of airflow limitation due to the workplace exposures. This method has some handicaps. PEFR is affected by the respiratory effort and the results are independent of a technician, requiring the collaboration of the worker. Therefore, monitoring PEF may allow for differentiating any overestimated or underestimated results from each other, however, it may be misused in regard to the issues associated with job loss or compensation [8].

Specific inhalation challenge test is currently recognized as the gold standard methods to diagnose OA. However, negative SIC test does not exclude OA. As all occupational diseases, accurate diagnosing $\mathrm{OA}$ constitutes the basis of curative treatment by removing the patient from the agent. Due to the medico-legal obligation, workers' disability and compensation rights, the most accurate methods should be used for diagnosing OA $[9,10]$. The diagnosis of $\mathrm{OA}$ should follow evidence-based guidelines. It should be remembered that negative test results do not exclude OA [11]. The aim of this study is to evaluate the comparison of SIC test results in patients with occupational and non-occupational asthma and to discuss PEFR monitoring and miss-diagnosis.

\section{Materials and Methods}

24 patients who underwent SIC test at the Health Science University Ataturk Chest Diseases and Thoracic Surgery Hospital Department of Occupational Diseases between July-December 2019 were analyzed. The study was designed as a retrospective cross-sectional study. Health Science University Ataturk Chest Diseases and Thoracic Surgery Hospital Institutional review board approval was obtained with 18 March-2021/718 decision/ protocol number.

\section{Data Collection}

Patients who were previously diagnosed with asthma by a physician and had asthmatic symptoms related to exposures at work environment and who were referred to our occupational disease's clinic with suspicion of work-related asthma were included in the study. Twenty-four patients who had a history of one or more specific exposure agents thought to cause asthma at the work environment and were performed with SIC and completed the test were included. Patients with a history of childhood asthma or asthma prior contact with the workplace exposure agent were excluded.

Specific Inhalation Challenge Test is carried out by an experienced occupational disease specialist physician who trained on Specific Inhalation Challenge Test. SIC test is performed at the hospital in a laboratory that is included an enclosed, dust and gas leak-proofed, air-fed, and well-aspirated cabin (Figure 1 and 2). Test records were accessed from the SIC test laboratory archive, and demographic information, radiological and laboratory records were accessed from hospital database named as 'Akgun'. Previous spirometric tests and methacholine bronchial provocation tests records were obtained from the hospital's Pulmonary Function Test unit. Hemogram, total IgE and Radioallergosorbent test (RAST) and specific IgE antibodies were examined in the hospital admissions of cases with suspected occupational asthma. These records were also accessed from the hospital database.

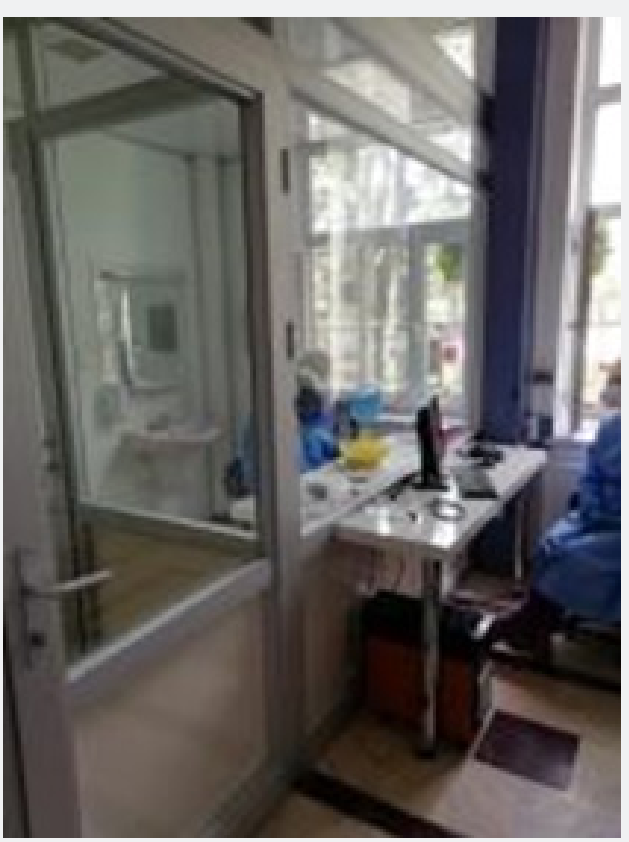

Figure 1: Specific Inhalation Challenge Test Laboratory at Health Science University Ataturk Chest Diseases and Thoracic Surgery Hospital, Department of Occupational Diseases. 


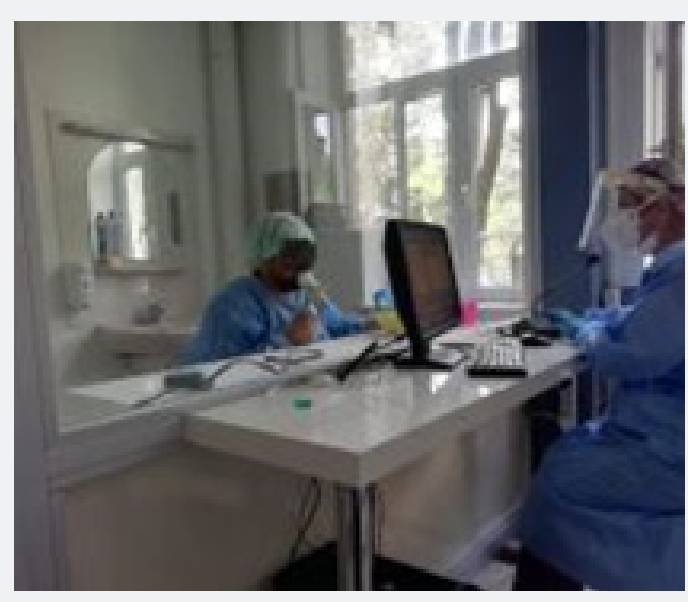

Figure 2: Performing Realist Test with Wheat Flour.

\section{Brinkman index and non-smoker definition}

The number of cigarettes smoked per day multiplied by the number of years of smoking was calculated. The definition of nonsmokers was those who smoked fewer than 100 cigarettes during their lifetime.

\section{Performing SIC Test}

Specific inhalation challenge test is performed using the realistic method in a $7 \mathrm{~m} 3$ cabin, as previously described [12-14]. The realistic approach aims to mimic the work environment as much as possible. For example, a baker is asked to toss flour from one tray to the other to produce airborne particles. This approach for performing SIC test has been shown to be safe and rarely induce severe asthmatic reactions requiring administration of systemic steroids [15]. The concentrations of the agents generated during the SIC test procedures were not quantified. Asthma medications were withdrawn according to their duration of action [16].

On the first day, the subjects were exposed to a "control" agent for 30 minutes to ensure that $\mathrm{FEV}_{1}$ fluctuations were $20 \%$ fall in $\mathrm{FEV}_{1}$ occurred or a cumulative exposure of 2 hours on the same day was completed. Those subjects who did not demonstrate a >_20\% fall in $\mathrm{FEV}_{1}$ during the first active challenge day systematically completed a second challenge for a maximum of 2 to 3 hours on the following day. Additional challenges were proposed when there was a significant [ $>3$-fold] decrease in the post-challenge PC20 value [17] was found as compared with the control day values [18]. ASIC test was considered positive when a reproducible fall in $\mathrm{FEV}_{1}$ of $20 \%$ or more as compared to prechallenge value was recorded.

\section{Recording PEFR at work and away from work}

Using a portable peak flow meter, patients were asked to measure PEF rates in sets of three repetitions, every two hours or at least four times per a day [the best measurement for each was recorded on a chart] for 15 days at rest, and 15 days at work. Occurrence of $20 \%$ diurnal PEF variability in at least $2 / 3$ of working days and maximum $1 / 7$ of resting days and worsening in PEF values in work vs. off work periods were considered to favor OA. Patents record their results at a daily card $[14,19]$.

\section{Statistical Analysis}

Variables were analyzed with SPSS-15 version program. Numerical variables that had homogeneous distribution analyzed with t-test, and categorical variables analyzed with chi-square test. Non-homogeneous variables analyzed with nonparametric tests. While comparing the control day numeric variables to exposure day numeric variables, ANOVA test was performed.

\section{Results}

\section{Demographics of patients}

A total of 24 patient files (Male: 21/ Female: 3) were reviewed. The mean age was $41.8 \pm 4.11$ years, the mean exposure period was $142.5 \pm 109.39$ months, and the mean time to onset of symptoms after starting work was $77.1 \pm 87.7$ years. Twenty-five percent ( $\mathrm{n}$ =6) of the patients had current smoking history and the mean of Brinkman index was $251.75 \pm 236.98$. 15 patients had history of using CS and the mean of CS dosage was $427.5 \mathrm{mcg}$. LMW agent exposure were $70.83 \%(n=17)$ of them. $66.66 \%(n=16)$ had positive reaction to aeroallergens in SIC test and diagnosed with OA. One patient who had borderline negative SIC was diagnosed with detecting 3 times fold in PC20 after the exposure. The majority of the patients were carpenter $(n=5)$ and baker $(n=5)$. Predicted $\mathrm{FEV}_{1}$ and $\mathrm{FEV}_{1} / \mathrm{FVC}$ means were $83.58 \pm 22.42 \%$ and $81.33 \pm 5.63 \%$, respectively. Except for two patients, 22 patients had at least 3 weeks PEF recording and only two patients had positive PEFR monitoring. Duration of PEFR monitoring mean was found $24.61 \pm 11.69$ days. 


\section{Comparison of $\mathrm{OA}$ and non-OA}

Twenty-four patients who underwent SIC test and 66.66 $\%(n=16)$ were diagnosed with OA. Although the number of patients exposed to LMW was higher in OA Group, total IgE level was higher in this group (OA total IgE: $697.39 \pm 839.36 \mathrm{kU} / \mathrm{ml}$;
non-OA total IgE $90.33 \pm 108.27 \mathrm{kU} / \mathrm{ml}$ ) (p: 0.0279 . All cases in the non-OA Group had exposure to LMW agents $(\mathrm{n}=8)$. Patients diagnosed with OA had respiratory symptoms and $50 \%(n=8)$ of them had conjunctivitis and $25 \%(n=4)$ had rhinitis. There was no significant relationship between two groups with duration of exposure (p: 0.973) (Table 1).

Table 1: The characteristics of patient with Occupational Asthma and non-Occupational Asthma.

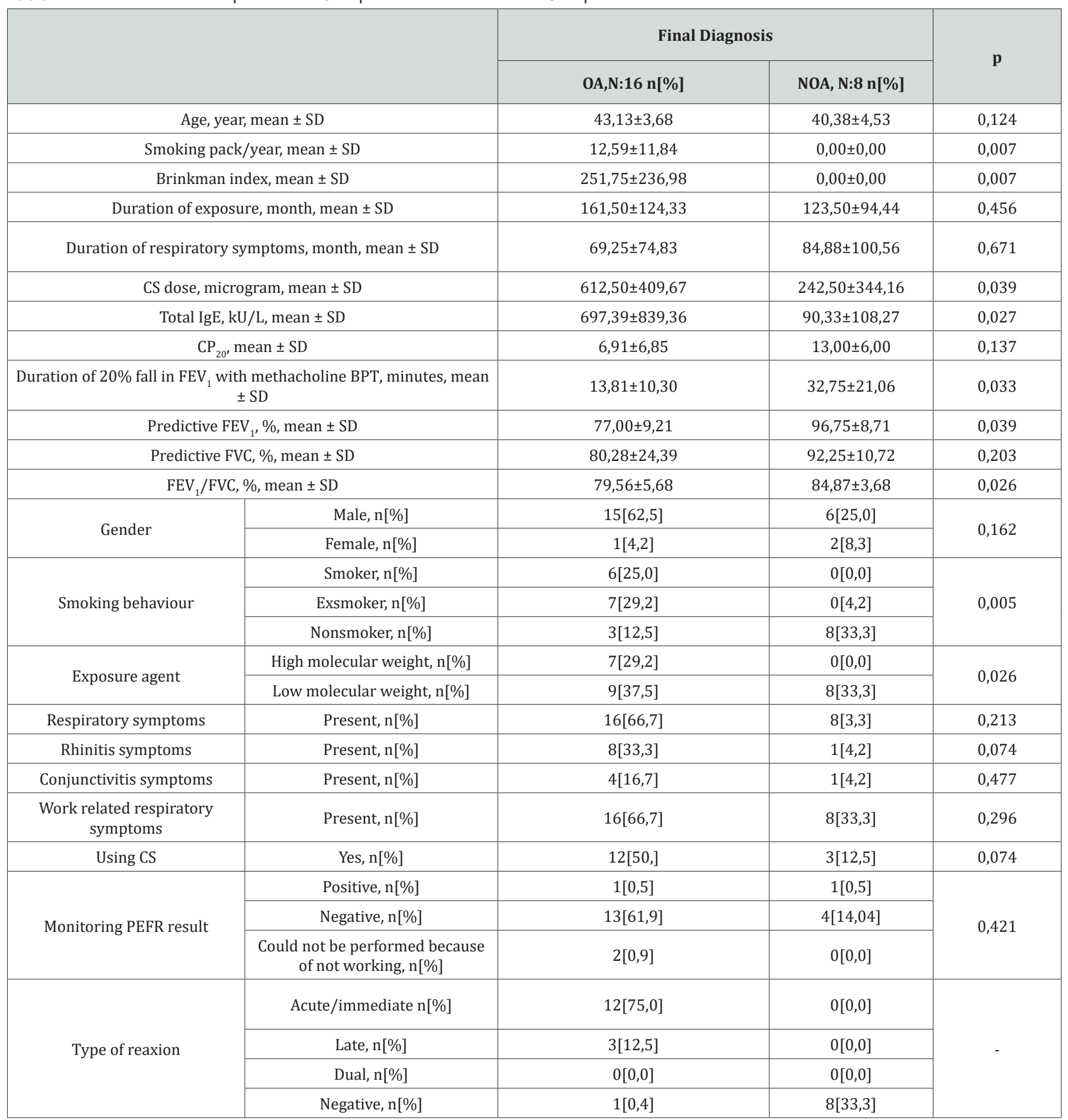

CS: Corticosteroid; $\mathrm{CP}_{20}$ : The provocative concentration of methacholine causing a $20 \%$ drop in $\mathrm{FEV}_{1}$; FEV $\mathrm{F}_{1}$ Forced expiratory volume in one second; FVC: Forced vital capacity; WBC: White blood count; OA: Occupational asthma; NOA: Non occupational asthma. 
Patients diagnosed with $\mathrm{OA}$ had only one patient positive PEFR monitoring. The average number of PEFR monitoring days of patients diagnosed with OA with the SIC test was $26.53 \pm$ 12.90. The $92.86 \%(n=13)$ patients who diagnosed with OA with SIC test was evaluated PEFR monitoring results were negative. The predicted $\mathrm{FEV}_{1}$ and $\mathrm{FEV}_{1} / \mathrm{FVC}$ ratio was lower in patients diagnosed with $\mathrm{OA}$ than in patients with non-OA (p: 0.026; p: 0.039). Although minimum $\mathrm{FEV}_{1}$ value at the end of the exposure day was lower in OA group than non-OA group (OA minimum $\mathrm{FEV}_{1}$ : $2.28 \pm 0.54 \mathrm{ml}$; non-OA minimum $\mathrm{FEV}_{1}: 3.26 \pm 0.70 \mathrm{ml}$ (p:0.001) (Table 1). The peripheral blood neutrophil count was higher in non-OA (p: 0.039) (Table 2), but there were no differences between the peripheral cell counts in control-exposure days and the groups (Table 3). In OA Group $75 \%(n=12)$ had immediate reaction.

Table 2: Comparison of the specific challenge test parameters of patients with occupational and non-occupational asthma.

\begin{tabular}{|c|c|c|c|c|}
\hline & & \multicolumn{2}{|c|}{ Final Diagnosis } & \multirow{2}{*}{$\mathbf{p}$} \\
\hline & & OA, $\mathrm{N}: 16$ Mean \pm SD & NOA, N:8 Mean \pm SD & \\
\hline \multirow{10}{*}{ Control Day } & Basal FEV ${ }_{1}, \mathrm{~L}$, mean $\pm \mathrm{SD}$ & $3,10 \pm 0,49$ & $3,63 \pm 0,94$ & 0,080 \\
\hline & Minimum $\mathrm{FEV}_{1}, \mathrm{~L}$, mean $\pm \mathrm{SD}$ & $2,83 \pm 0,63$ & $3,45 \pm 1,01$ & 0,083 \\
\hline & Basal FEV $_{1} / \mathrm{FVC} \%$, mean $\pm \mathrm{SD}$ & $84,32 \pm 8,50$ & $81,37 \pm 9,85$ & 0,458 \\
\hline & Minimum $\mathrm{FEV}_{1} / \mathrm{FVC} \%$, mean $\pm \mathrm{SD}$ & $78,33 \pm 9,11$ & $80,20 \pm 13,86$ & 0,695 \\
\hline & Maximum PEF, ml, mean \pm SD & $416,25 \pm 96,39$ & $436,25 \pm 134,15$ & 0,678 \\
\hline & minimum PEF ml, mean \pm SD & $322,50 \pm 87,21$ & $378,75 \pm 144,06$ & 0,244 \\
\hline & White cell count, $x 10^{3} / \mu$ mean \pm SD & $7562,00 \pm 1632,32$ & $22000,00 \pm 39901,39$ & 0,165 \\
\hline & Neutrophil, $\times 10^{3} / \mu \mathrm{l}$, mean $\pm \mathrm{SD}$ & $4360,00 \pm 1074,64$ & $3944,28 \pm 2360,61$ & 0,571 \\
\hline & Eosinophil, $\mathrm{x} 10^{3} / \mu \mathrm{l}$, mean $\pm \mathrm{SD}$ & $404,00 \pm 355,88$ & $868,57 \pm 1060,80$ & 0,136 \\
\hline & Lymphocyte, $\mathrm{x} 10^{3} / \mu \mathrm{l}$, mean $\pm \mathrm{SD}$ & $2439,33 \pm 951,48$ & $2378,57 \pm 730,87$ & 0,883 \\
\hline \multirow{13}{*}{ Exposure Day } & Basal FEV $1, \mathrm{~L}$, mean $\pm \mathrm{SD}$ & $3,14 \pm 0,40$ & $3,70 \pm 0,88$ & 0,044 \\
\hline & Minimum $\mathrm{FEV}_{1}, \mathrm{~L}$, mean $\pm \mathrm{SD}$ & $2,28 \pm 0,54$ & $3,26 \pm 0,70$ & 0,001 \\
\hline & Basal FEV $_{1} / \mathrm{FVC}, \%$, mean $\pm \mathrm{SD}$ & $81,01 \pm 4,63$ & $83,35 \pm 9,14$ & 0,410 \\
\hline & Minimum $\mathrm{FEV}_{1} / \mathrm{FVC}, \%$, mean $\pm \mathrm{SD}$ & $76,41 \pm 12,29$ & $81,83 \pm 10,31$ & 0,296 \\
\hline & Maximum PEF, ml, mean \pm SD & $416,25 \pm 106,76$ & $407,50 \pm 121,97$ & 0,858 \\
\hline & Minimum PEF, ml, mean \pm SD & $276,25 \pm 122,73$ & $353,12 \pm 153,83$ & 0,197 \\
\hline & Maximum temperature, ${ }^{\circ} \mathrm{C}$, mean $\pm \mathrm{SD}$ & $36,76 \pm 0,28$ & $36,72 \pm 0,31$ & 0,772 \\
\hline & Duration of exposure, day, mean \pm SD & $203,62 \pm 182,37$ & $381,87 \pm 255,17$ & 0,061 \\
\hline & Maximum $20 \%$ fall in $\mathrm{FEV}_{1}, \%$ & $29,86 \pm 11,51$ & $11,77 \pm 3,98$ & 0,000 \\
\hline & White cell count, $x 10^{3} / \mu \mathrm{l}$, mean $\pm \mathrm{SD}$ & $7628,18 \pm 1449,26$ & $8712,00 \pm 880,38$ & 0,148 \\
\hline & Neutrophil, $x 10^{3} / \mu \mathrm{l}$, mean $\pm \mathrm{SD}$ & $4041,81 \pm 1046,86$ & $5262,00 \pm 837,09$ & 0,039 \\
\hline & Eosinophil, $\mathrm{x} 10^{3} / \mu \mathrm{l}$, mean $\pm \mathrm{SD}$ & $228,18 \pm 157,46$ & $324,00 \pm 176,43$ & 0,294 \\
\hline & Lymphocyte, $\mathrm{x} 10^{3} / \mu \mathrm{l}$, mean $\pm \mathrm{SD}$ & $2346,00 \pm 1213,04$ & $6386,40 \pm 10225,94$ & 0,199 \\
\hline
\end{tabular}

$\mathrm{FEV}_{1} ; \mathrm{FEV}_{1}$ : Forced expiratory volume in one second; FVC: Forced vital capacity; OA: Occupational asthma; NOA: Non occupational asthma. 
Table 3: Comparison of the peripheral white blood, neutrophil, eosinophil and lymphocyte count before and after the exposure in patients with occupational and non-occupational asthma.

\begin{tabular}{|c|c|c|c|c|c|c|c|c|c|}
\hline & \multirow{3}{*}{ Parameters } & \multicolumn{4}{|c|}{ OA, N:11 } & \multicolumn{4}{|c|}{ NOA, N: 5} \\
\hline & & \multirow[t]{2}{*}{ Mean \pm SD } & \multicolumn{2}{|c|}{$\begin{array}{l}95 \% \text { Confidence } \\
\text { Interval of the } \\
\text { Difference }\end{array}$} & \multirow[t]{2}{*}{$\mathbf{p}$} & \multirow[t]{2}{*}{ Mean \pm SD } & \multicolumn{2}{|c|}{$\begin{array}{l}\text { 95\% Confidence } \\
\text { Interval of the } \\
\text { Difference }\end{array}$} & \multirow[t]{2}{*}{$\mathbf{p}$} \\
\hline & & & Lower & Upper & & & Lower & Upper & \\
\hline \multirow{2}{*}{ Pair 1} & $\begin{array}{l}\text { Control day WBC, } \times 10^{3} / \\
\mu \mathrm{l}\end{array}$ & $7421,81 \pm 1760,82$ & \multirow{2}{*}{$-1106,10$} & \multirow{2}{*}{693,37} & \multirow{2}{*}{0,620} & $28154,40 \pm 47117,09$ & \multirow{2}{*}{$-38428,83$} & \multirow{2}{*}{77313,63} & \multirow{2}{*}{0,404} \\
\hline & $\begin{array}{c}\text { Exposure day WBC, } \\
\mathrm{x} 10^{3} / \mu \mathrm{l}\end{array}$ & $7628,18 \pm 1449,26$ & & & & $8712,00 \pm 880,38$ & & & \\
\hline \multirow{2}{*}{ Pair 2} & $\begin{array}{l}\text { Control day neutrophil, } \\
\qquad \mathrm{x} 10^{3} / \mu \mathrm{l}\end{array}$ & $4270,00 \pm 1241,28$ & \multirow{2}{*}{$-580,20$} & \multirow{2}{*}{1036,57} & \multirow{2}{*}{0,543} & $4621,20 \pm 1977,55$ & \multirow{2}{*}{$-2473,35$} & \multirow{2}{*}{1191,75} & \multirow{2}{*}{0,387} \\
\hline & $\begin{array}{l}\text { Exposure day neutro- } \\
\text { phil, } \mathrm{x} 10^{3} / \mu \mathrm{l}\end{array}$ & $4041,81 \pm 1046,86$ & & & & $5262,00 \pm 837,09$ & & & \\
\hline \multirow{2}{*}{ Pair 3} & $\begin{array}{l}\text { Control day eosinophil, } \\
\qquad \times 10^{3} / \mu \mathrm{l}\end{array}$ & $462,72 \pm 400,90$ & \multirow{2}{*}{$-30,85$} & \multirow{2}{*}{499,94} & \multirow{2}{*}{0,077} & $502,00 \pm 558,18$ & \multirow{2}{*}{$-363,18$} & \multirow{2}{*}{719,18} & \multirow{2}{*}{0,413} \\
\hline & $\begin{array}{l}\text { Exposure day eosino- } \\
\text { phil, } x 10^{3} / \mu \mathrm{l}\end{array}$ & $228,18 \pm 157,46$ & & & & $324,00 \pm 176,43$ & & & \\
\hline \multirow{2}{*}{ Pair 4} & 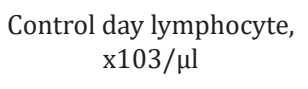 & $2489,09 \pm 1023,92$ & \multirow{2}{*}{$-997,89$} & \multirow{2}{*}{1284,07} & \multirow{2}{*}{0,786} & $2367,40 \pm 422,76$ & \multirow{2}{*}{$-16524,64$} & \multirow{2}{*}{8486,64} & \multirow{2}{*}{0,423} \\
\hline & $\begin{array}{l}\text { Exposure day l lympho- } \\
\text { cyte, } \mathrm{x} 103 / \mu \mathrm{l}\end{array}$ & $2346,00 \pm 1213,04$ & & & & $6386,40 \pm 10225,94$ & & & \\
\hline
\end{tabular}

WBC: White blood count; OA: Occupational asthma; NOA: Non occupational asthma.

Table 4: Comparison of some spirometer parameters and peripheral neutrophil, eosinophil counts before and after the exposure to the HMW and LMW agents in patients with OA

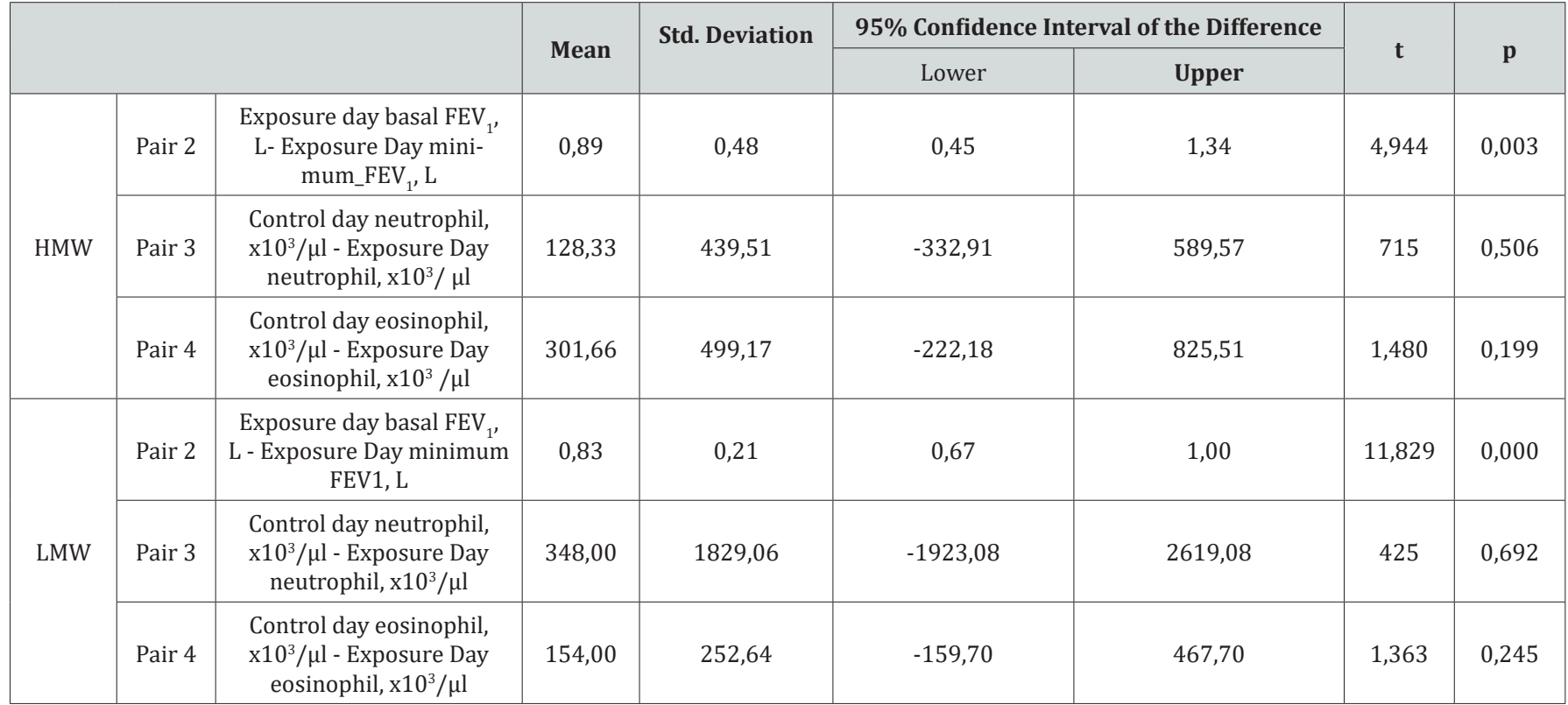

FEV $\mathrm{f}_{1}$ Forced expiratory volume in one second; FVC: Forced vital capacity; HMW: High molecular weight; LMW: Low molecular weight. 
Comparison of exposure type with $\mathrm{FEV}_{1}$ on control and exposure days in patients diagnosed with OA was statistically significant for both LMW (Low Molecular Weight) and HMW (High Molecular Weight) agents. But we could not find relationship between the type of exposure agent and peripheral blood neutrophil and eosinophil counts during the performing SIC test (Table 4).

\section{Discussion}

Nowadays, PEFR monitoring is widely used to diagnose OA when SIC test is not accessible. Although negative SIC test could not completely exclude OA, PEFR monitoring at work and away from work causes serious concerns about the sensitivity. In our study, we found that the PEFR variability was negative in the SIC test positive patients except for one (92.86\%).

Occupational asthma diagnosis is made by history and objective evidence of reversible airway obstruction. A detailed medical and exposure history is critical in the diagnosis of OA. The history should include a detailed assessment of the workplace environment, the work process, changes in symptoms in and away from work, associated dermatological or upper respiratory symptoms, and a review of relevant material safety data sheets that provide clues regarding exposure and the potential causes. Although the patients were not observed in the working environment, the agents they were exposed to and causing respiratory complaints could be identified with a detailed occupational history, in our study. It was determined that exposure to LMW agent was the highest. With the detailed medical history, we found that respiratory symptoms were accompanied by rhinitis and conjunctivitis.

It is known that Skin Prick Test (SPT), total IgE or radioallergosorbent test (RAST) alone is not sufficient to show respiratory sensitizer or to confirm OA. Bardy et al. showed that SPT / RAST tests, positive and negative predictive values for psyllium were $22 \% / 16 \%$ and $100 \% / 100 \%$, respectively [20]. Although these tests are helpful methods in diagnosis, their standardization is insufficient for many antigens [21]. Nevertheless, IgE plays a key role in asthma pathogenesis. In our study, we found that the total IgE level was significantly higher in patients with OA compared to non-OA. Similar to the Woszczek et al. detected relationship between asthma and high total IgE level [22], we showed that the total IgE level is higher in OA.

Asthma that occurs with HMW agents mostly induces IgE mediated responses. Wheat flour specific IgE was found positive in $6.5 \%$ of 392 bakers exposed to wheat flour, and it was found that associated with respiratory symptoms [23]. IgE-mediated responses in workers exposed to wheat are associated with workrelated symptoms. Serum-specific IgE against wheat flour can be a potential biomarker to identify asymptomatic sensitized workers or to predict the phenotype of baker's asthma. Even though the specific IgE against wheat flour is thought to have diagnostic value, it is unknown for the other HMW allergens such as rye flour, enzymes, or fungi.

In our study, although the total IgE level was found significantly higher in patients with OA than in non-OA patients, when the total IgE level was compared with HMW and LMW agents. Also, there was no significant difference between job tasks and total IgE in patients with OA or non-OA. Also, we could not find relationship between the changes peripheral blood eosinophil counts in control and exposure days and two groups. Therefore, our study supported that high total IgE level alone cannot be used in the diagnosis of OA. One of the limitations of our study was induced sputum cell counts, RAST or SPT was not applied to every patient who underwent SIC test.

PEF is a portable and cost-effective device that it is widely used by physicians to diagnose occupational asthma. Ideal PEFR monitoring is performed with measurements every 2 hours for at least 2 weeks at work and at least 2 weeks away from work. It is recommended to take at least 4 measurements in a day. Moore et al. reported that recording PEFR for 8 days at work and 3 days away from work with the least eight times in a day, the sensitivity was $68 \%$ and the specificity was $91 \%$ [24]. While PEFR monitoring was performed, it is recommended that subjects allowed to use short-acting beta- 2 agonists and inhaled steroids. It is known that false-positive PEF variability was related to reducing or discontinuing inhaled steroids. It is also shown that using steroids does not change the result of SIC TEST.

We found that patients who were performed with SIC test and followed-up with PEFR, was continued with the same dose steroid. Interestingly, it was detected that in OA group steroid dose was significantly higher than in non-OA group. This result suggests that use of high-dose steroids does not change the result of SIC.

PEF results are recorded by the employees, and it may cause inconsistency in the records. Records reliability affects the diagnostic sensitivity and specificity of PEFR monitoring results. It was observed that performing PEF less than 2.5 weeks or 4 times in a day was decreased the sensitivity and specificity [25]. Our study was shown that PEF monitoring periods [duration of monitoring PEFR mean $=26.53 \pm 12.90$ days $]$ were performed based on suggesting literature and as well as Turkey Social Security Institution.

The most reliable analysis method for PEFR records is computer packages programs. OASYS is the most commonly used program that is developed by Gannon et al. [26-28] Mccoach at al. reported that using a computer program was affected relevant PEFR monitoring, and they showed sensitivity was $75 \%$ and specificity was $94 \%$ [29]. Annes W et al. reported that while PEF measurements recorded by employees, the compliance of the PEFR monitoring was found $\% 6$, and if a respiratory physiologist was made it was increased $\% 15$. They were also shown the quality of 
PEFR records is best when recorded on dedicated diary cards [30]. Due to the retrospective study in our study was not used computer packages PEFR monitoring programs. It was the limitation of our study. Nevertheless, in our clinic PEFR monitoring is trained by a physician and given to subjects dedicated diary cards.

A study was determined that $56 \%$ of the patient's made sufficient PEF measurements while made themselves, and this rate increased to $85 \%$ in the measurements made by the patients at the hospital [31]. Nevertheless, as in the COVID-19 pandemic, it is difficult to use PEF device while using compulsory respiratory protective equipment, and perform PEF in the workplace, and also part-time workers have difficulty to performing and analyzing their records [32]. All these factors affect the reliability of PEF. Although there are assertive studies to successful method to diagnosing $\mathrm{OA}[33,34]$. there are not few studies showing that it is inadequate to diagnosing and determining the specific agent $[14,35]$. Nevertheless, the PEFR monitoring method is suggested for patients who cannot SIC due to severe asthma and $\mathrm{FEV}_{1}$ below $70 \%$, and if the agent causing asthma cannot be detected or presence multiple exposure agents [36].

Specific Inhalation Challenge Testis accepted as the reference and gold standard test all over the world to confirm and diagnose OA [37,38]. This method, which aims to mimic workplace exposures in hospital at a laboratory, and it can also perform at workplace. The SIC test is safe when performed under the close supervision of a qualified doctor and by trained personnel Resuscitative measures should be easy to available. Therefore, it is limited to specialist centers. Although there is no standardized protocol, the methodology is well developed [39]. The test can be easily applied to outpatients. A European task force reported that SIC testing could be performed in 24 centers from 12 countries in Europe $[40,41]$. Our SIC test laboratory is the first unit offering services in the Department of Occupational Diseases in Turkey which is established on the basis of international standards (Figure 1 and 2).

Patients may not know what agents were used at work. It is suggested more information should be obtained from management safety data sheets in the workplace [14]. Sozener et al. reported that obtaining information about exposure from patients and that neither safety data sheets nor workplace inspection documents were included in the referral files sent by the social security institution [42]. Failure to specify the exposure agent with the disease may cause problems with medico-legal procedures. Therefore, it can be said that SIC test is a more reliable diagnostic method than PEFR monitoring to show a direct relationship between exposure agents and asthma In addition, PEF monitoring is not suitable to diagnose patients who have left their jobs. Another limitation of PEF is that it causes false OA diagnosis due to the 'morning dip' effect in the PEFR measurements performed after the workers wake up late in their resting periods due to the change in PEFR measurements due to circadian rhythm and diurnal rhythm [43, 44]. As emphasized before, it is recommended that diagnosing $\mathrm{OA}$ with monitoring PEFR is while there are difficulties to access SIC test and there are multiple workplace exposures.

\section{Conclusion}

PEF monitoring is insufficient to diagnose OA. In order to differentiate work-related asthma from general asthma and to make an accurate diagnosis, the employee should be referred to a specialist center where the SIC test is performed. SIC is the most objective test performed in the workplace or in the laboratory for medico-legal reasons such as ensuring the termination of exposure, which is the most effective treatment method, and the lack of loss of rights in compensation procedures.

\section{References}

1. Fernandez-Nieto M, Quirce S, Sastre J (2006) Occupational asthma in industry. Allergol Immunopathol [Madr] 34[5]: 212-223.

2. Hawley B, Cummings KJ, Mohammed M, Dimmock AE, Bascom R (2017) Allergic sinusitis and severe asthma caused by occupational exposure to locust bean gum: Case report. Am J Ind Med 60 [7]: 658-663.

3. Badar S, Ahmed SW, Mahmood ZA, Khaliq SA, Azhar I, et al. (2016) Occupational asthma: Contribution of smoking and hereditary effects. Iran J Public Health 45[7]: 956-957.

4. Tarlo SM, Lemiere C (2014) Occupational Asthma. N Engl J Med 370[7]: 640-649.

5. Burge PS, O Brien IM, Harries MG (1979) Peak flow rate records in the diagnosis of occupational asthma due to isocyanates. Thorax 34[3]: 317-323.

6. Cartier A, Pineau L, Malo J (1984) Monitoring of maximum expiratory peak flow rates and histamine inhalation tests in the investigation of occupational asthma. Clin Exp Allergy 14[2]: 193-196.

7. Cote J, Kennedy S, Chan-Yeung M (1990) Sensitivity and specificity of PC20 and peak expiratory flow rate in cedar asthma. J Allergy Clin Immunol 85[3]: 592-598.

8. Quirce S, Sastre J (2011) New causes of occupational asthma. Curr Opin Allergy Clin Immunol 11(2): 80-5.

9. Tarlo SM (2015) The role and interpretation of specific inhalation challenges in the diagnosis of occupational asthma. Can Respir J 22[6]: 322-323.

10. Cullinan P, Munoz X, Suojalehto H, Raymond A, Surinder J, et al. (2017) Occupational lung diseases: from old and novel exposures to effective preventive strategies. Lancet Respir Med 5[5]: 445-455.

11. Tarlo SM (2008) Occupational Exposures and Adult Asthma. Immunol Allergy Clin North Am 28[3]: 563-576.

12. D Alpaos V, Vandenplas O, Evrard G, Jamart J (2013) Inhalation challenges with occupational agents: Threshold duration of exposure. Respir Med 107[5]: 739-744.

13. Vandenplas O, Suojalehto H, Aasen TB, Xaver B, PS Burge, et al. (2014) Specific inhalation challenge in the diagnosis of occupational asthma: Consensus statement. Eur Respir J 43: 1573-1587

14. Tarlo SM, Balmes J, Balkissoon R, Jeremy B, W Beckett, et al. (2008) Diagnosis and management of work-related asthma: American College of Chest Physicians consensus statement. Chest 134(3 Suppl): 1S-41S.

15. O Vandenplas, VD Alpaos, G Evrard, J Jamart (2013) Incidence of severe asthmatic reactions after challenge exposure to occupational agents. Chest 143(5): 1261-1268. 
16. Juniper EF, Kline PA, Vanzieleghem MA, Ramsdale EH, O Byrne PM, et al. (1990) Effect of long-term treatment with an inhaled corticosteroid [budesonide] on airway hyperresponsiveness and clinical asthma in nonsteroid-dependent asthmatics. Am Rev Respir Dis 142[4]: 832836

17. Vandenplas O, Delwiche JP, Jamart J, Van de Weyer R (1996) Increase in non-specific bronchial hyperresponsiveness as an early marker of bronchial response to occupational agents during specific inhalation challenges. Thorax 51[5]: 472-478.

18. Lemiere C, Nguyen S, Sava F, VD Alpaos, F Huaux, et al. (2014) Occupational asthma phenotypes identified by increased fractional exhaled nitric oxide after exposure to causal agents. J Allergy Clin Immunol 134[5]: 1063-1067.

19. Çelebi SZ, Aydin O, Demirel YS, Soyyigit Ş, Çerçi P, et al. (2017) Does the medical diagnosis of occupational asthma coincide with the legal diagnosis? J Asthma 54[9]: 930-937.

20. Bardy JD, Malo JL, Seguin P, H Ghezzo, J Desjardins, et al. (1987) Occupational asthma and $\operatorname{IgE}$ sensitization in a pharmaceutica company processing psyllium. Am Rev Respir Dis 135[5]: 1033-1038.

21. Cartier A, Grammer L, Malo JL, F Lagier, H Ghezzo, et al. (1989) Specific serum antibodies against isocyanates: Association with occupational asthma. J Allergy Clin Immunol 84[4 Part 1]: 507-514.

22. Woszczek G, Kowalski ML, Borowiec M (2002) Association of asthma and total IgE levels with human leucocyte antigen-DR in patients with grass allergy. Eur Respir J 20[1]: 79-85

23. Jesus M, Carmona C, Evrand G, Fitzgerald B, Paule M (2013) Handbook of Procedures for Specific Inhalation Challenge European Taskforce on SIC June 2013 Compiled by Katri Suuronen, Hille Suojalehto and Paul Cullinan, on behalf of the ERS Task Force on Specific Inhalation Challenges with Occupational Agents.

24. Moore VC, Jaakkola MS, Burge CB, Charles F Pantin, Alastair SR, et al. (2009) PEF analysis requiring shorter records for occupational asthma diagnosis. Occup Med [Lond] 59[6]: 413-417.

25. V Huggins, W Anees, Burge PS (2001) Reliability of PEF diaries. Thorax 56: 742 .

26. Gannon PF, Newton DT, Belcher J, Pantin CF, Burge PS (1996) Development of OASYS-2: a system for the analysis of serial measurement of peak expiratory flow in workers with suspected occupational asthma. Thorax 51[5]: 484-489.

27. Bright P, Newton DT, Gannon PF, C F Pantin, P S Burge (2001) OASYS-3: improved analysis of serial peak expiratory flow in suspected occupational asthma. Monaldi Arch Chest Dis 56(3): 281-288.

28. Baldwin DR, Gannon P, Bright P, DT Newton, A Robertson, et al. (2002) Interpretation of occupational peak flow records: level of agreement between expert clinicians and Oasys-2. Thorax 57[10]: 860-864.

29. Burge PS, Pantin CF, Newton DT, PF Gannon, P Bright, et al. (1999) Development of an expert system for the interpretation of serial peak expiratory flow measurements in the diagnosis of occupationa asthma. Midlands Thoracic Society Research Group. Occup Environ Med 56[11]: 758-764.
30. Anees W, Moore VC, Burge PS (2006) FEV1 decline in occupational asthma. Thorax 61[9]: 751-755.

31. Huggins V, Anees W, Pantin C, Burge S (2005) Improving the quality of peak flow measurements for the diagnosis of occupational asthma. Occup Med [Lond] 55[5]: 385-8.

32. Kennedy WA, Girard F, Chaboillez S, Andre C, Johanne C, et al. (2007) Cost-effectiveness of various diagnostic approaches for occupational asthma. Can Respir J 14[5]: 276-280.

33. Moore VC, Jaakkola MS, Burge PS (2011) A Systematic Review of Serial Peak Expiratory Flow Measurements in the Diagnosis of Occupational Asthma. European Respiratory Journal 38[55]: p4941.

34. Leroyer C, Perfetti L, Trudeau C, JL Archeveque, M Chan-Yeung, et al. (1998) Comparison of serial monitoring of peak expiratory flow and FEV1 in the diagnosis of occupational asthma. Am J Respir Crit Care Med 158[3]: 827-832.

35. Nicholson PJ, Cullinan P, Newman TAJ, Burge PS, Boyle C (2005) Evidence based guidelines for the prevention, identification, and management of occupational asthma. Occup Environ Med 62(5): 290299.

36. Perrin B, Cartier A, Ghezzo H, L Grammer, K Harris, et al. (1991) Reassessment of the temporal patterns of bronchial obstruction after exposure to occupational sensitizing agents. J Allergy Clin Immunol 87(3): 630-639.

37. Newman Taylor AJ, Cullinan P, Burge PS, P Nicholson, C Boyle (2005) BOHRF guidelines for occupational asthma. Thorax 60(5): 364-366.

38. Cruz MJ, Munoz X (2012) The current diagnostic role of the specific occupational laboratory challenge test. Curr Opin Allergy Clin Immunol 12(2): 119-125.

39. Cartier A, Bernstein IL, Sherwood BP, JR Cohn, LM Fabbri, et al. (1989) Guidelines for bronchoprovocation on the investigation of occupational asthma. Relines of the subcommittee on Bronchoprovocation for occupational asthma. J Allergy Clin Immunol 84(5 Pt 2): 823-829.

40. Vandenplas O, Suojalehto H, Aasen TB, Xaver B, P Sherwood B, et al. (2014) Specific inhalation challenge in the diagnosis of occupational asthma: Consensus statement. Eur Respir J 43(6): 1573-1587.

41. Suojalehto H, Cullinan P (2014) Specific inhalation challenge tests for occupational asthma in Europe: a survey. Eur Respir Rev (132): 266270 .

42. Celebi SZ, Aydin O, Demirel YS, Sadan S, Pamir C, et al. (2017) Does the medical diagnosis of occupational asthma coincide with the legal diagnosis? J Asthma 54(9): 930-937.

43. Reinberg A, Clench J, Aymard N, M Galliot, R Bourdon, et al. (1975) [Circadian variations of the effects of ethanol and of blood ethanol values in the healthy adult man. Chronopharmacological study]. J Physiol (Paris) 70(4): 435-456.

44. Kurashima K, Tako T, Takayanagi N, Hiroo S, Daido T, et al. (2005) Evening Dip of Peak Expiratory Flow in Patients with Asthma; Allergology International 54(2): 325-329. 
Your next submission with Juniper Publishers will reach you the below assets

- Quality Editorial service

- Swift Peer Review

- Reprints availability

- E-prints Service

- Manuscript Podcast for convenient understanding

- Global attainment for your research

- Manuscript accessibility in different formats ( Pdf, E-pub, Full Text, Audio)

- Unceasing customer service

Track the below URL for one-step submission https://juniperpublishers.com/online-submission.php 